\title{
MÁS PRECISIONES SOBRE ALGUNAS OBRAS DE MICHAEL COXCIE EN ESPAÑA: LA LAMENTACIÓN SOBRE LIENZO DE EL ESCORIAL Y LA RESURRECCIÓN DE CRISTO DEL ANTIGUO CONVENTO DE LOS AGUSTINOS DE MEDINA DEL CAMPO (VALLADOLID)
}

\author{
Ana Diéguez Rodríguez \\ (Instituto Moll. Centro de investigación en pintura flamenca- \\ Universidad de Burgos)
}

\section{RESUMEN}

En este trabajo se revisan los aspectos documentales de dos obras de Michiel Coxcie en España. Una es el lienzo de una Lamentación que se encontraba en el siglo XVII en El Escorial, y que actualmente se guarda en la iglesia de San Ginés de Madrid y, el otro, es una Resurrección que Ponz describe en el antiguo convento de Nuestra Señora de Gracia de Medina del Campo (Valladolid). Obra que se consideraba perdida pero cuya descripción coincide con una tabla del mismo asunto en el mercado internacional. Lo interesante de esta escena es que, entre las pinturas del mismo asunto conservadas de Coxcie, es la más cercana al modelo que ideó el pintor flamenco en el fresco perdido de la Resurrección de la antigua basílica de San Pedro en Roma.

PALABRAS CLAVE: Michiel Coxcie, pintura flamenca, siglo XVI, El Escorial, Medina del Campo

\section{MORE INFORMATION ABOUT SOME PAINTINGS OF MICHAEL COXCIE IN SPAIN: THE LAMENTATION ON CANVAS OF EL ESCORIAL AND THE RESURRECTION OF CHRIST AT THE ANCIENT CONVENT OF THE AGUSTINES IN MEDINA DEL CAMPO (VALLADOLID)}

\begin{abstract}
This article reviews the documentary sources in relation with two paintings of Michiel Coxcie in Spain. One is the Lamentation, which was in El Escorial at 17th century, and nowadays is at the Saint Ginés church in Madrid. The other is a Resurrection that was described by Ponz in the ancient convent of Our Grace Lady in Medina del Campo (Valladolid). This painting whereabouts was unknown until it is related in this article with one at the international trade. The composition of this painting should have been
\end{abstract}


the closer to the model painted by Coxcie at the lost fresco at the ancient basilica of Saint Peter in Rome.

KEYWORDS: Michiel Coxcie, Flemish painting, 16th century, El Escorial, Medina del Campo 